\title{
Penanganan Perilaku Seksual Pada Remaja Tunagrahita di Panti Sosial Bina Grahita Harapan Ibu Kalumbuk Padang
}

\author{
Johandri Taufan ${ }^{1}$,Riza Nopala Sari ${ }^{2}$, Nurhastuti ${ }^{3}$ \\ ${ }^{123}$ Universitas Negeri Padang,Indonesia \\ Email: johandri.taufan@fip.unp.ac.id
}

\section{INFORMASI ARTIKEL}

Terkirim Day-Month-Year

Revisi Day-Month-Year

Diterima Day-Month-Year

\section{Kata kunci:}

Perilaku Seksual, Tunagrahita

\begin{abstract}
ABSTRAK
Artikel merupakan hasil penelitian yang dilatar belakangi banyaknya bentuk perilaku seksual yang muncul pada remaja tunagrahita, seperti mansturbasi atau onani, mempertontonkan alat kelamin dimuka umum, pacaran sudah tidak sesuai dengan norma-norma yang berlaku. Pembahasan pada artikel ini bertujuan untuk mengetahui dan mendeskripsikan upaya penangan yang dilakukan pembimbing terhadap penyimpangan perilaku seksual yang dilakukan remaja tunagrahita. Metode penelitian yang digunakan adalah metode deskriptif kualitatif dengan subjek penelitian ini adalah pembimbing panti yang berjumlah 5 orang. Teknik pengumpulan data menggunakan teknik observasi, teknik wawancara, dan study dokumentasi. Hasil penelitian ini menunjukkan bahwa upaya yang dilakukan pembimbing dalam menangani perilaku seksual pada remaja tunagrahita. secara verbal dengan menasehatinya, mengingatkan dan memberikan intruksi pada saat remaja sedang melakukan perilaku seksual dengan menggunakan bahasa yang mudah dimengerti remaja tunagrahita. Secara non verbal dalam menangani perilaku dengan mengadakan seminar tentang kesehatan reproduksi. Penangan perilaku seksual pada remaja tunagrahita dengan bentuk pengalihan aktivitas fungsional memberikan punishment (hukuman).
\end{abstract}

\section{Pendahuluan}

Setiap individu akan melewati beberapa tahapan-tahapan dalam rentang kehidupan salah satunya masa remaja. Masa remaja adalah masa peralihan dari masa kanak-kanak menuju masa dewasa, dimana masa itu terjadi pertumbuhan yang pesat termasuk fungsi reproduksi sehingga mempengaruhi terjadinya perubahan-perubahan perkembangan, baik secara fisik, mental, maupun peran sosial.

Perubahan yang terjadi pada remaja meliputi perubahan fisik, yang diikuti munculnya tanda-tanda seks primer dan sekunder. Pada masa remaja juga terjadinya perubahan hormonal, diantara hormon-hormon yang dikeluarkan oleh kelenjer bawah otak berpengaruh pada seksualitas, yaitu hormon androgen dan testoteron yang menyebabkan timbulnya birahi (nafsu seks, libido). Dorongan seks ini yang dapat diaplikasikan dalam bentuk perilaku seksual. Bentuk-bentuk tingkah laku ini bisa bermacam-macam, mulai dari perasaan tertarik sampai tingkah laku berkencan, bercumbu, dan bersenggama Objek seksualnya bisa berupa orang lain atau diri sendiri, hal ini juga dialami oleh semua remaja, termasuk remaja tunagrahita. Pada dasarnya anak tunagrahita memiliki kebutuhan yang sama dengan anak pada umumnya. Dalam perkembangan manusia ada delapan kebutuhan yang merupakan tahaptahap perkembangan kepribadian, yang mana kebutuhan ini juga menjadi kebutuhan juga bagi anak tunagrahita. Namun karena keterlambatan dalam perkembangan kecerdasannya, anak tunagrahita akan mengalami hambatan untuk memenuhi kebutuhan-kebutuhan tersebut, bahkan diantara mereka ada yang hanya mencapai sebagian atau kurang, tergantung pada berat ringannya hambatan yang dimiliki anak serta perhatian yang diberikan oleh lingkungannya. Remaja tunagrahita merupakan individu yang memiliki karakteristik yang sedemikian rupa, yang memiliki kecerdasan atau intelegensi dibawah rata-rata, kurang dapat menyesuaikan diri terhadap lingkungan, terjadi pada masa perkembangan. Walaupun kondisi mental dibawah normal, namun organ-organ seksualnya berkembang secara normal. Remaja tunagrahita sering menunjukkan perilaku seksualnya di tempat umum, hal ini dikarenakan mereka tidak dapat mengendalikan dan mengontrol dorongan seks yang terjadi secara naluriah.

Remaja tunagrahita pada umumnya kekurangan informasi yang berhubungan dengan perkembangan seksualitas. Hal tersebut disebabkan tidak didapatkannya informasi mengenai pendidikan seksual dari orang tua. Orang tua kurang berminat untuk memberikan pemahaman pendidikan seksual kepada remaja tunagrahita Akibatnya remaja tunagrahita tidak mempunyai pengetahuan yang cukup untuk tentang informasi pendidikan seksual. Oleh karena itu, remaja tunagrahita sering mengalami masalah kekerasan seksual karena keterbatasan remaja tunagrahita dalam pengetahuan, sering dianggap remeh, dianggap bodoh dan dapat dibohongi karena ketidaktahuan mereka (www.detiknew.com, 2009). Pendidikan seksual mengenai bagian-bagian anggota tubuh, kegunaan, serta cara merawat anggota tubuh tersebut masih sering dianggap tabu atau tidak wajar untuk diajarkan oleh orang tua kepada remaja tunagrahita.

Permasalahan perilaku seksual pada remaja tunagrahita ditemukan di Panti Sosial Bina Grahita Harapan Ibu Kalumbuk Padang. Menurut hasil wawancara dan observasi. Pembimbing banyak menangani masalah bentuk perilaku seksual yang muncul pada remaja tunagrahita yang laki-laki melakukan mansturbasi atau onani. Memainkan organ reproduksi ketika remaja tunagrahita sendiri di pojok-pojok asrama. Menyalurkan dorongan seksualnya secara spontan dengan menggosokan alat kelaminnya pada sesama temannya ataupun pada benda misalnya dinding sampai keluar air mani. Para remaja perempuan yang mulai pacaran sudah tidak sesuai dengan norma-norma yang berlaku. misalnya berjalan bergandengan, berpelukan, berciuman, meraba-raba tubuh dan alat kelamin lawan jenis.

Berdasarkan kondisi dan permasalahan di atas, perlu kiranya pengkajian yang mendalam melalui sebuah penelitian, dan penulis tertarik untuk meneliti lebih dalam tentang upaya pembimbing dalam menangani perilaku seksual pada remaja tunagrahita di PSBGHI. Masalah dalam penelitian yang diteliti dibatasi dan difokuskan pada permasalahan yaitu mengetahui gambaran yang mendalam tentang. Upaya penangan yang dilakukan pembimbing asrama terhadap penyimpangan perilaku seksual yang dilakukan remaja tunagrahita di Panti Sosial Binagrahita Harapan Ibu Kalumbuk Padang. Kendala 
yang dihadapai oleh pembimbing asrama dalam menangani penyimpangan perilaku seksual yang dilakukan remaja tunagrahita di Panti Sosial Binagrahita Harapan Ibu Kalumbuk Padang. Cara pembimbing asrama mengatasi kendala yang dihadapai dalam menangani penyimpangan perilaku seksual yang dilakukan remaja tunagrahita di Panti Sosial Binagrahita Harapan Ibu Kalumbuk Padang

\section{Metode}

Penelitian ini menggukan jenis penelitian deskiptif kualitatif. Subjek penelitian dalam penelitian ini adalah pembimbing panti, sedangkan sumber data pendukung yakni kepala panti, dan instruktur. Penelitian ini mengumpulkan data dengan menggunakan teknik Teknik pengumpulan data menggunakan teknik observasi yang berpedoman pada pedoman observasi dijelaskan dengan menggunakan catatan lapangan, teknik wawancara yang berpedoman pada pedoman wawancara dijelaskan dengan menggunakan catatan wawancara, dan menggunakan teknik dokumentasi yang berbentuk foto dan video. Lokasi penelitian pada penelitian ini adalah di Panti Sosial Binagrahita Harapan Ibu Kalumbuk Padang terletak di Jln. Wisma bunda kelurahan. Kalumbuk kecamatan. Kuranji RT. IV. RW II Padang. Data yang telah didapat selama penelitian akan diperiksa dengan menggunakan teknik keabsahan data seperti perpanjangan pengamatan, meningkatkan ketekunan, triangulasi, menggunakan bahan referensi, mengadakan member check.

\section{Hasil Penelitian dan Pembahasan}

\section{Hasil Penelitian}

1. Upaya penangan yang dilakukan pembimbing asrama terhadap penyimpangan perilaku seksual yang dilakukan remaja tunagrahita di Panti Sosial Binagrahita Harapan Ibu Kalumbuk Padang.

Upaya yang dilakukan pembimbing dalam menangani perilaku seksual secara verbal dengan menasehatinya, remaja yang perempuan dinasehati pula oleh pembimbing perempuan, dan remaja yang laki-laki juga dinasehati juga oleh pembimbing laki-laki. Mengingatkan dan memberikan intruksi secara situasional pada saat remaja sedang melakukan perilaku seksual maupun diberbagai kesempatan dengan menggunakan bahasa Indonesia atau bahasa induk yang mudah dimengerti remaja tunagrahita dan menghindari istilah-istilah yang sulit untuk dimengerti remaja tunagrahita. Contoh seperti apa-apa saja yang tidak boleh dipegang orang lain, apa-apa saja yang tidak boleh dilakukan terhadap kemaluan sendiri, apa-apa saja yang tidak boleh dilakukan terhadap perempuan dan tidak boleh berpelukan baik teman laki-laki maupun perempuan. Penanganan yang dilakukan dengan strategi larangan yang diberikan lebih cenderung kepada larangan yang diberikan lebih cenderung berupa verbal (kalimat) dilakukan pembimbing dengan melarang "stop", "jangan", dan "tidak". Selain larangan juga memberikan intruksi lanjutan untuk aktifitas lainnya dengan kata singkat seperti "stop garuk-garuk!", “jangan digaruk-garuk nanti lecet!". "RS...tangan!", menyebut nama, dan mengacungkan jari telunjuk. Setiap pembimbing berbeda-beda dalam memberi larangan, yang terpenting harus sering memberi larangan karena remaja sering lupa untuk tidak menunjukan perilaku seksual yang tidak wajar. Memberikan layanan informasi apa saja bagian tubuh yang tidak boleh dipegang dan diraba oleh sembarangan orang. Layanan seperti ini termasuk kedalam layanan program khusus dipanti ini.

Upaya penanganan yang dilakukan secara non verbal Penangan perilaku seksual pada remaja tunagrahita dengan bentuk pengalihan aktivitas fungsional dilakukan dengan cara pembimbing mengalihkan perilaku remaja ke aktivitas di jam itu. Misal pada saat remaja sedang duduk-duduk. Ketika remaja tunagrahita memuncul perilaku seksual memegang kemaluan. pembimbing langsung mengalihkan dengan melakukan kegiatan meminta remaja membersihkan asrama, atau menjahit. Selain pengalihan aktivitas remaja tunagrahita, pengalihan aktivitas fungsional dilakukan dengan cara memberikan aktivitas atau yang remaja tunagrahita senangi atau sukai, seperti pembimbing mengalihkan dengan kegiatan diaula misal nya kegiatan menari dan bermain musik, atau mendatangi remaja tunagrahita dan mengalihkan perilaku seksual dengan cara mengajak mengobrol. Penangan perilaku seksual pada remaja tunagrahita dengan bentuk pengalihan aktivitas fungsional dilakukan dengan cara pembimbing mengalihkan perilaku remaja ke aktivitas di jam itu. Misal pada saat remaja sedang duduk-duduk, ketika remaja tunagrahita memuncul perilaku seksual memegang kemaluan. Pembimbing langsung mengalihkan dengan melakukan kegiatan meminta remaja membersihkan asrama. Mengadakan seminar tentang kesehatan reproduksi. Memindahkan asrama adapun disatu sisi asrama yang lain ada temannya yang suka melakukan menyimpangan perilaku seksual jadi ada yang terbawah-bawah untuk melakukan untuk itu dilakukan pemindahah asrama. Punishment yang diberikan seperti menskor remaja tunagrahita tersebut. Tidak boleh keluar asrama paling lama dua minggulah, paling cepat satu minggu. Artinya dia tidak boleh bermain dilingkungan asrama. Reward yang diberikan seperti diberi suatu makanan misalnya dibawah membeli sate, atau bakso dengan motivasi seperti itu dia mau meninggalkan perilaku seperti itu. Penanganan terakhir, nanti pihak panti dikantor akan mengadakan sebuah rapat yang diberi nama rapat ACC. TIM ACC kepala panti, psikolog, BK, fungsional, dan pembimbing. Rapat ACC ini memutuskan bahwasannya bagaimana nanti remaja tunagrahita ini untuk kedepannya, karena kalau dibiarkan saja akan berdampak bagi yang lain. Jadi tindakan tegasnya bisa jadi pemulangan kembali kepada orang tuanya. Hal itu sudah pernah dilakukan.

2. Kendala Yang Dihadapai Oleh Pembimbing Asrama Dalam Menangani Penyimpangan Perilaku Seksual Yang Dilakukan Remaja Tunagrahita Di Panti Sosial Binagrahita Harapan Ibu Kalumbuk Padang.

Kendala yang dihadapi oleh pembimbing dalam menangani penyimpangan perilaku seksual yang dilakukan remaja tunagrahita di panti sosial bina grahita harapan ibu kalumbuk padang. Kendala dalam hal sarana dan prasarana kurang CTTV di dalam ruangan asrama, untuk saat ini CCTV baru ada dilingkungan panti mulai dari gerbang masuk dan dilingkungan belajar, sedangkan untuk didalam ruangan panti itu belum ada. Hal ini membuat keterbatasan pembimbing untuk memantau segala aktivitas remaja termasuk didalam kamar mandi. Pembimbing sangat berharap CCTV akan ada didalam ruangan asrama. Sedangkan untuk kendala kerjasama sendiri tidak ada masalah yang siginifikan semua pihak bekerja sama dengan baik dengan seluruh pihak panti dengan kepala panti, pekerja sosial, fungsional panti, intruktur, psikologi, BK, dokter, dan pembimbing panti. Seluruh pihak panti memilik tugasnya masing-masing dan secara berkala akan mengadakan rapat dan evaluasi terkait upaya penanganan dalam menangani perilaku seksual remaja tunagrahita.

3. Usaha Pembimbing Asrama Mengatasi Kendala Yang Dihadapai Dalam Menangani Penyimpangan Perilaku Seksual Yang Dilakukan Remaja Tunagrahita Di Panti Sosial Binagrahita Harapan Ibu Kalumbuk Padang.

Usaha pembimbing untuk mengatasi kendala yang dihadapi dalam menangani penyimpangan perilaku seksual yang dilakukan remaja tunagrahita di Panti Sosial Bina Grahita Harapan Ibu Kalumbuk Padang, dengan melakukan kerjasama yang baik dengan seluruh pihak panti dengan kepala panti, pekerja sosial, fungsional panti, intruktur, psikologi, BK, dokter, dan pembimbing panti. Seluruh pihak panti memilik tugas nya masingmasing dan secara berkala akan mengadakan rapat dan evaluasi terkait upaya penanganan dalam menangani perilaku seksual remaja tunagrahita.

\section{PEMBAHASAN}

Penanganan perilaku seksual pada remaja tunagrahita sejalan dengan penerapan penanganan menurut Sri (2016: 680), yaitu penanganan yang dilakukan dengan strategi diantaranya : 1) larangan, 2) pengalihan aktivitas fungsional, 3) pengarahan tempat. Penanganan perilaku seksual remaja tunagrahita berupa larangan, pengalihan aktivitas fungsional, dan pengarahan tempat. Panti Sosial Bina Grahita Harapan Ibu Kalumbuk Padang sudah 
menggunakan prosedur larangan dan pengalihan aktivitas fungsional dalam penanganan perilaku seksual remaja tunagrahita. contoh yang dilakukan oleh guru dengan mengingatkan dengan lisan bentuk peringatan yaitu dengan "stop", "jangan", dan "tidak". Selain larangan juga memberikan intruksi lanjutan untuk aktifitas lainnya dengan kata singkat seperti "stop garuk-garuk!", “jangan digaruk-garuk nanti lecet!". "RS...tangan!”, menyebut nama, dan mengacungkan jari telunjuk. Setiap pembimbing berbeda-beda dalam memberi larangan, yang terpenting harus sering memberi larangan karena remaja sering lupa untuk tidak menunjukan perilaku seksual yang tidak wajar.

Menurut Martin dan Pear ( 2015:329) punishment adalah konsekuensi langsung yang diberikan kepada perilaku operan yang menyebabkan perilaku tersebut menurut frekuensinya. Sekali saja sebuah kejadian ditetapkan untuk berfungsi sebagai penghukum bagi perilaku tertentu seorang individu disituasi tertentu, maka kejadian tersebut bisa digunakan untuk menurunkan perilaku operan invidu tersebut disituasi-situasi lain. Sesuai dengan hukuman jika, disituasi tertentu, seseorang melakukan sesuatu yang langsung diikuti sebuah penghukuman, makai ia akan berkurang kecenderungannya untuk melakukan hal yang sama saat kemudian hari menjumpai situasi yang serupa. Berdasarkan hasil penelitian di Panti Sosial Bina Grahita Harapan Ibu Kalumbuk Padang pembimbing melakukan punishment dalam bentuk seperti menskor remaja tunagrahita tersebut. Tidak boleh keluar asrama paling lama dua minggulah, paling cepat satu minggu. Artinya dia tidak boleh bermain dilingkungan asrama. Sejalan dengan menurut pendapat Menurut Anggara (2016:5) sebelum diberikan perlakuan dengan prosedur aversi perilaku onani anak sangat tinggi. Pada saat diberikan perlakuan dalam mengurangi perilaku seksual menyimpang tampak berkurang. Setelah diberhentikan perilaku menyimpang anak juga tampak berkurang. Penghukuman sering disebut aversi.

Pemberian penguatan positif atau reward sejalan dengan pendapat Martin dan Pear (2015:87) menyatakan bahwa jika seseorang disituasi tertentu melakukan sesuatu yang diikuti langsung oleh sebuah penguatan positif, maka akan cenderung melakukan hal yang sama disaat berikutnya disetuasi yang sama. Berdasarkan hasil penelitian di Panti Sosial Bina Grahita Harapan Ibu Kalumbuk Padang pembimbing memberikan reward kepada remaja yang berhasil mengurangi perilaku seksual.

Kendala yang dihadapi oleh pembimbing dalam menangani penyimpangan perilaku seksual yang dilakukan remaja tunagrahita di Panti Sosial Bina Grahita Harapan Ibu Kalumbuk Padang. Kendala dalam hal sarana dan prasarana kurang CTTV di dalam ruangan asrama, untuk saat ini CCTV baru ada dilingkungan panti mulai dari gerbang masuk dan dilingkungan belajar, sedangkan untuk didalam ruangan panti itu belum ada. Hal ini membuat keterbatasan pembimbing untuk memantau segala aktivitas anak termasuk didalam kamar mandi. Pembimbing sangat berharap CCTV akan ada didalam ruangan asrama. Sedangkan untuk kendala kerjasama sendiri tidak ada masalah yang siginifikan semua pihak bekerja sama dengan baik dengan seluruh pihak panti dengan kepala panti, pekerja sosial, fungsional panti, intruktur, psikologi, BK, dokter, dan pembimbing panti. Seluruh pihak panti memilik tugasnya masing-masing dan secara berkala akan mengadakan rapat dan evaluasi terkait upaya penanganan dalam menangani perilaku seksual remaja tunagrahita.

Kenapa penting nya pengadaan CCTV bagi ruangan panti hal dikarena mengingat besarnya manfaat cetv itu sendiri seperti yang dikemukan oleh Riski (2016: 29) CCTV (closed circuit television) merupakan sebuah perangkat kamera video digital yang digunakan untuk mengirim sinyal kelayar monitor disuatu ruangan atau memantau situasi dan kondisi disuatu tempat, sehingga mencegah terjadinya kejahatan atau dapat dijadikan barang bukti dari kejahatan yang telah terjadi. Hal ini juga didukung menurut Abidin (2017: 40) pemasangan cctv di Mtsn banda aceh sangat bermanfaat bagi guru, dengan adanya cctv perubahan tingkah laku siswa siswa dari hari kehari dapat dirasakan kearah yang lebih baik dan meningkatkan kedisiplinan.

Sistem pengawasan cctv dipanti adalah cara untuk memastikan keamanan dan lingkungan. Seluruh kegiatan ataupun aktivitas remaja tunagrahita tidaklah mudah untuk dipantau secara keseluruhan oleh pembimbing. jadi pemanfaatan cetv digunakan untuk mengoptimalkan pemantauan semua aktivitas yang terjadi didalam asrama tersebut

\section{Kesimpulan}

Hasil penelitian ini menunjukkan bahwa upaya yang dilakukan pembimbing dalam menangani perilaku seksual pada remaja tunagrahita. secara verbal dengan menasehatinya, cenderung mengingatkan dan memberikan intruksi secara situasional pada saat remaja sedang melakukan perilaku seksual maupun diberbagai kesempatan dengan menggunakan bahasa Indonesia atau bahasa induk yang mudah dimengerti remaja tunagrahita dan menghindari istilah-istilah yang sulit untuk dimengerti remaja tunagrahita. Verbal (kalimat) dilakukan pembimbing dengan melarang "stop", "jangan", dan "tidak". Selain larangan juga memberikan intruksi lanjutan untuk aktifitas lainnya dengan kata singkat seperti "stop garuk-garuk!", "jangan digaruk-garuk nanti lecet!". "RS...tangan!", menyebut nama siswa, dan mengacungkan jari telunjuk. Upaya penanganan yang dilakukan secara non verbal dalam menangani perilaku dengan mengadakan seminar tentang kesehatan reproduksi. Penangan perilaku seksual pada remaja tunagrahita dengan bentuk pengalihan aktivitas fungsional dilakukan dengan cara pembimbing mengalihkan perilaku remaja ke aktivitas di jam itu. Misal pada saat remaja sedang duduk-duduk, ketika remaja tunagrahita memuncul perilaku seksual memegang kemaluan guru langsung mengalihkan dengan melakukan kegiatan meminta remaja membersihkan asrama, atau menjahit. Memberikan aktivitas atau yang remaja tunagrahita senangi atau sukai, seperti pembimbing mengalihkan dengan kegiatan menari dan bermain musik. Memberikan Punishment (hukuman) seperti menskor remaja tunagrahita tersebut. Tidak boleh keluar asrama paling lama dua minggulah, paling cepat satu minggu. Penangan terakhir dengan melakukan rapat ACC.

\section{Saran}

Saran yang dapat diberikan bagi kepala panti, pembimbing, orang tua dan peneliti selanjutnya, sebagai berikut:

1. Kepala Panti

Kepala panti perlu melengkapi sarana dan prasarana guna untuk mendukung dalam menangani perilaku seksual pada remaja tunagrahita, selain itu kepala panti perlu membuat kebijakan khusus terkait strategi dalam menangani perilaku seksual sehingga penanganan dapat dilakukan sesuai dengan prosedur dan kebutuhan remaja tunagrahita, dapat disosialisasikan kepada guru dengan baik, dapat diimplementasikan secara sistematis dan terukur.

2. Pembimbing

Pembimbing penting mengetahui dan mengenali karakteristik dan kebutuhan remaja tunagrahita. selain itu, guru perlu meningkarkan wawasan dan mencari penanganan yang paling efektif untuk menangani perilaku seksual pada remaja tunagrahita. serta membuat program bimbingan seks mengingat hal itu sangat penting untuk mendapatkan perhatian khusus.

3. Orang Tua

Orang tua perlu bekerjasama dengan pembimbing dalam mengimplementasikan penangan yang diberikan pembimbing diasrama pada saat remaja tunagrahita pulang kampung sehingga ada kesinambungan antara penanganan di panti dan dirumah.

4. Peneliti Selanjutnya

bagi peneliti selanjutnya, dapat dijadikan acuan dan bahan referensi untuk melaksanakan maupun melanjutkan penelitian tentang pendidikan seks dan sampai pembuatan program bimbingan seks. 
Daftar Rujukan

Anggara, Soni. (2016). Efektifitas Prosedur Aversi Untuk Mengurangi Perilaku Menyimpang Pada Anak Tunagrahita Ringan di SLB Amal Bhakti Sicincin. Vol 5. No 1

Aziz, Safrudin. (1014). Pendidikan seks bagi anak berkebutuhan khusu. Jurnal kependidikan. Vol. 2. No 2.

Batubarra, Jose. (2010). Perkembangan Remaja. Jurnal Pediatri. Vol. 12. No. 1

Efendi, M. (2009). Pengantar psikopedagogik anak berkelainan. Jakarta: PT Bumi Aksara.

Haryani, Mulya. (2012). Dampak Pornografi Terhadap Perilaku Siswa Dan Upaya Guru Pembimbing Untuk Mengatasinya. Jurnal Ilmiah Konseling. Vol. 1. No. 1.

Kemis, Ati Rosnawati. (2013). Pendidikan anak berkebutuhan khusus tunagrahita. Jakarta:LuximaMetro Media.

Kosasih, E.(2012). Cara bijakmemahami anak berkebutuhan Khusus. Bandung: Yhara Widia.

Kumalasari, I., \& Andhyantoro, I. (2012). Kesehatan reproduksi. Jakarta: Salemba Medika.

Kumalasari, Fani. (2012). Hubungan Antara Dukungan Sosial Dengan Penyesuaian Diri Remaja di Panti Asuhan. Jurnal Psikologi. Vol. 1. No. 1.

Mansur, H., \& Budiarti, T. (2014 ). Psikologi ibu dan anak. Jakarta: Salemba Medika.

Margono.(2014). Metodologi penelitian pendidikan. Jakarta: RinekaCipta.

Martin, Gerry \& Pear, Joseph. (2015). Modifikasi Perilaku. Yogyakarta: Pustaka Pelajar.

Moh, Amin. 1995. Ortopedagogik anak tunagrahita. Bandung : depdikbud.

Papalia, D. E., \& Feldman, R. D. (2014). Menyelami perkembangang manusia. Jakarta: Salemba Humanika.

Praptiningrum, N. (2006). Pendidikan seksual bagi anak tunagrahita. Jurnal Pendidikan khusus. Vol.2. No. 1.

Praytino, \& Emti, A. (2015). Dasar-dasar bimbingan dan konseling. Jakarta: PT Rineka Cipta.

Santrock, J. W. (2007). Remaja. Jakarta: Erlangga.

Sarwono, S. W. (2003). Psikologi remaja. Jakarta: PT. Grafindo Permata.

2012. Psikologi remaja. Jakarta: PT. Grafindo Permata.

Sugiyono. (2014). Penelitian kualitatif, kuantitatif dan $R \& D$. Bandung: Penerbit Alfabeta.

Suharsimi Arikunto. (2014). Prosedur Penelitian: Suatu Pendekatan Praktis. Jakarta: Rineka Cipta. 2016. Metode penelitian kombinasi (Mixed Methods). Bandung: Alfabeta.

Sumekar, Ganda.( 2009). Anak berkebutuhan khusus. Padang: UNP Press.

Sunarto, \& Hartono, A. (2013). Perkembangan peserta didik. Jakarta: Rineka Cipta. Tunagrahita.Jakarta:LuximaMetro Media.

Taufan, J., \& Mazhud, F. (2016). Kebijakan-kebijakan Kepala Sekolah Dalam Penyelenggaraan Pendidikan Inklusif Di Sekolah X Kota Jambi. Jurnal Penelitian Pendidikan, 14(1)

Utami, Sri Santi. (2016). Strategi Penanganan Preventif-Kuratif Perilaku Seksual Pada Remaja Autis SLB Fredofios Yogyakarta. Jurnal Widia Ortodidaktika. Vol. 5. No. 7.

Walgito, Bimo. (2010). Pengantar Psikologi Umum. Yogyakarta : Andi.

WinaSanjaya. (2013). Penelitian Pendidikan. Jakarta: Kharisma Putra Utama. 